\title{
Opuntia humifusa Supplementation Reduces Fat Weight by Increasing PPAR- $\gamma$ and PGC-1a Protein Expression in the Skeletal Muscle of Rats
}

\author{
Daekeun Kwon, Junyong Kang, Jaeseung Kim and Youngju Song* \\ Laboratory of Sports Nutrition, Sunmoon University, Asan-si, Chung Nam, 336-708, Korea
}

Received October 30, 2013 /Revised December 31, 2013 /Accepted January 22, 2014

\begin{abstract}
This study was conducted to investigate the effects of supplementation with Opuntia humifusa on the expression of peroxisome proliferator-activated receptor-delta (PPAR- $\delta$ ), peroxisome proliferator-activated receptor-gamma (PPAR- $\gamma$ ) and peroxisome proliferator-activated receptor gamma coactivator1alpha (PGC-1a) in the skeletal muscle of rats fed a high-fat diet. Sixteen Sprague-Dawley male rats at 6 weeks of age were randomly divided into 2 groups: a control diet group (CG, $n=8)$ and an experimental diet group (EG, $n=8)$. The rats were fed a high-fat diet (CG) or a high-fat diet supplemented with $5 \%$ O. humifusa (EG) for 8 weeks. The results showed that the abdominal fat pad and epididymal fat pad weights were significantly lower in the EG than in the CG $(p<0.01)$. In the blood, serum glucose, triglycerides, and total cholesterol in the EG group were lower than in the CG $(p<0.01)$. The expression of PPAR- $\gamma$ and PGC-1a protein in the skeletal muscle of the EG was increased compared with that of the CG $(p<0.05)$. These results indicate that 8 weeks of $O$. humifusa supplementation lowers serum glucose and triglyceride levels and suppresses weight gain by reducing fat weight through an increase in the expression of PPAR- $\gamma$ and PGC- $1 a$ in the muscle tissue of rats.
\end{abstract}

Key words : High-fat diet, Opuntia humifusa, PPAR- $\delta$, PPAR- $\gamma$, PGC-1a

\section{Introduction}

Peroxisome proliferator-activated receptors (PPARs), which are nuclear hormone receptors that activate lipid metabolism pathways such as lipogenesis and lipolysis, are well known to play an important role in maintaining cholesterol and lipid homeostasis. PPARs also regulate the genes involved in the metabolic regulation of lipoproteins, the activity of insulin and the differentiation of adipocytes [6]. PPAR$\delta$ is expressed in various tissues, particularly in muscle tissue, and is involved in the modulation of lipid catabolism and energy uncoupling in skeletal muscles [5]. In addition, PPAR- $\gamma$ regulates fat storage and adipocyte metabolism [27], and it has been reported that PPAR- $\gamma$ is involved in modulating insulin sensitivity in the body [26]. Furthermore, PGC-1 a, which is a transcriptional coactivator associated with PPARs expression in tissues, is a regulator of mitochondria biogenesis and lipid metabolism activation $[2,12]$. In particular, it has been reported that PGC-1a is highly expressed

\section{*Corresponding author}

Tel : +82-41-530-2239, Fax : +82-41-530-2810

E-mail : song6711@sunmoon.ac.kr.

This is an Open-Access article distributed under the terms of the Creative Commons Attribution Non-Commercial License (http://creativecommons.org/licenses/by-nc/3.0) which permits unrestricted non-commercial use, distribution, and reproduction in any medium, provided the original work is properly cited. in brown adipose tissue, which is known to have a high capability for oxidation as well as activated transcription of PPAR- $\gamma[20,29]$.

In a previous study that related the reduction of fat weight and PPARs, Wang et al. [32] reported that activation of PPAR- $\delta$ decreased fat mass due to an increase in fatty acid oxidation and utilization in adipocytes and muscle tissues, and it has been reported that reduced expression of PPAR- $\gamma$ protein in white adipose tissue affected body weight and reduced fat weight [30]. However, although the expression of PPAR- $\gamma$ is low in muscle, previous studies have suggested that lipid metabolism is related to PPAR- $\gamma$ protein expression in muscle tissue. Norris et al. [22] reported that body weight significantly increased in PPAR- $\gamma$ knockout mouse muscle tissue, in contrast with was observed in adipocytes. Nevertheless, although the protein expression of PPAR- $\gamma$ and PGC-1a was increased in rat muscle tissue, body and fat weight was not affected. Therefore, PPAR proteins are expressed according to tissue-specific patterns.

Recently, many studies and development processes have focused on functional food, which can safely be ingested without toxicity as a long-term treatment, to activate lipid metabolism. Approximately 4,000 types of cacti exist in the world, and as a plant that is highly adaptable to semi-arid areas, some varieties have been used as a source of carbohydrates and various vitamins. Particularly used in South 
Korea, $O$. humifusa, a tropical plants containing fruits on the stems, is a member of Cactaceae family that has been cultivated to grow in cold environment below $-20^{\circ} \mathrm{C}$ [8]. O. humifusa contains not only minerals, such as calcium, magnesium, zinc, and ferrum but also soluble fiber, vitamin- C, vitaminE, flavonoids, and polyphenols. It has been reported that these nutritional compounds play a predominant role in the physiological function of the body [10]. In a previous study, Dok-go et al. [4] described that supplementation with $O$. ficus-indica, which is repleted with flavonoids such as quercetin that act as antioxidants, exhibited anti-inflammatory effects and neuroprotective effects against oxidative injuries induced in cortical cell cultures in rats. It has been reported that cactus extract supplementation protects the gastric mucous membrane and suppresses carrageenan-induced edema and beta-glucuronidase and lysosomal enzyme secretion in neutrophils [24]. Although various research has been performed that reported that $O$. humifusa supplementation has a positive effect on the physiological function to the body, there have not been any studies designed to evaluate the protein expression related to fatty acids regulation by $O$. humifusa.

Therefore, in this study, we investigated the effects of $O$. humifusa supplementation on body weight and changes in fat weight as well as on PPAR- $\gamma, \delta$ and PGC-1a protein expression, which plays an important role in transcriptional gene regulation of fatty acid metabolism in muscle tissue, in high-fat diet-induced rats.

\section{Materials and Methods}

\section{Experimental animals}

All experimental protocols were approved by the Animal Study Committee of Sunmoon University. After the acclimatization period during week one, sixteen 6-week-old male Sprague-Dawley rats (Samtaco Bio Korea, Hwaseong, Korea) were randomly divided into two groups: a control diet group (CG: high-fat diet group, $\mathrm{n}=8$ ) and an experimental diet group (EG: $5 \%$ O. humifusa supplemented diet group, $\mathrm{n}=8$ ), given free access to tap water and food for 8 weeks, and housed in groups of two per cage under controlled temperature $\left(23 \pm 1^{\circ} \mathrm{C}\right)$ and relative humidity $(50 \pm 5 \%)$. The light/dark cycle was automatically controlled (alternating 12-h periods), and lighting began at 8:00 pm. Food intake was measured daily and body weight was measured weekly. At the end of the experimental period, the rats were anes- thetized with diethyl ether after fasting for $12 \mathrm{~h}$. Blood samples were taken from the left ventricle and serum was obtained by centrifuging the blood at $700 \times g$ for $20 \mathrm{~min}$ at $4^{\circ} \mathrm{C}$. Both hind limb muscles were dissected and immediately immersed in liquid nitrogen. The serum samples and hind limb muscles were stored at $-70^{\circ} \mathrm{C}$ until analyzed.

\section{Preparation of experimental diet}

$O$. humifusa, which was harvested in Asan, Chungnam, was cleaned and blended using a HMF-3150S blender (Hanil Electronics, Seoul, Korea). After blending, the $O$. humifusa was frozen in a freezer at a temperature of $-70^{\circ} \mathrm{C}$ and then freeze-dried in a freeze dryer (Ilshin Co., Gyeonggi, Korea). After freeze-drying, as shown in Table 1, a general component analysis of $O$. humifusa was performed using the Association of Official Analytical Chemists (AOAC) method for the following measurements: moisture, using an air-oven method; ash, using a dry-ashing method; carbohydrates, using calculation; crude protein, using a Keldahl method; crude fat, using a Soxhlet extraction method; and fiber, using an enzymatic-chemical method. Mineral component analysis was performed using plasma atomic emission spectrometry (ICP-AES) to determine the composition of $\mathrm{Fe}^{2+}, \mathrm{Ca}^{2+}, \mathrm{Mg}^{2+}$, $\mathrm{K}^{+}, \mathrm{Na}^{+}$, and $\mathrm{P}^{2+}$. As shown in Table 2, the high-fat diet was composed of $20 \%$ protein, $48 \%$ carbohydrate and $20 \%$ fat and was modified from a previous study [18] and based on AIN-76G. The 5\% O. humifusa diet was made by substituting a portion of carbohydrates, protein, fiber, and fat components of the high-fat diet. During the experimental period, the diet was prepared in batches sufficient for 3-5 days, and the experimental diets were stored at $4^{\circ} \mathrm{C}$ to maintain freshness.

Table 1. Composition of freeze-dried $O$. humifusa

\begin{tabular}{|c|c|}
\hline Ingredients & Contents \\
\hline Moisture $(\% \mathrm{w} / \mathrm{w})$ & 2.9 \\
\hline Ash $(\% \mathrm{w} / \mathrm{w})$ & 13.8 \\
\hline Carbohydrate $(\mathrm{g} / 100 \mathrm{~g})$ & 46.6 \\
\hline Crude protein $(\mathrm{g} / 100 \mathrm{~g})$ & 4.9 \\
\hline Crude fat (g/100 g) & 3.1 \\
\hline Fiber $(\mathrm{g} / 100 \mathrm{~g})$ & 28.9 \\
\hline $\mathrm{Fe}^{2+}(\mathrm{mg} / \mathrm{g})$ & 5.8 \\
\hline $\mathrm{Ca}^{2+}(\mathrm{mg} / 100 \mathrm{~g})$ & 2931.3 \\
\hline $\mathrm{Mg}^{2+}(\mathrm{mg} / 100 \mathrm{~g})$ & 1227.9 \\
\hline $\mathrm{K}^{+}(\mathrm{mg} / 100 \mathrm{~g})$ & 2155.5 \\
\hline $\mathrm{Na}^{+}(\mathrm{mg} / 100 \mathrm{~g})$ & 30.9 \\
\hline $\mathrm{P}^{2+}(\mathrm{mg} / 100 \mathrm{~g})$ & 653.2 \\
\hline
\end{tabular}


Table 2. Composition of the experimental diet ( $\mathrm{g} / \mathrm{kg}$ diet)

\begin{tabular}{lcc}
\hline Ingredients & $\begin{array}{c}\text { High-fat } \\
\text { diet }\end{array}$ & $\begin{array}{c}\text { Diet with 5\% } \\
\text { O. humifusa }\end{array}$ \\
\hline Casein & 200 & 197.6 \\
Starch & 111 & 87.8 \\
Sucrose & 370 & 370 \\
Lard & 170 & 170 \\
Corn oil & 30 & 28.4 \\
Cellulose & 50 & 35.6 \\
Vitamin mix. & 12 & 12 \\
Mineral mix. & 42 & 42 \\
Cholesterol & 10 & 10 \\
D,L-methionine & 3 & 3 \\
Choline barbiturate & 2 & 2 \\
Tert-butylhydroquinone & 0.04 & 0.04 \\
O. humifusa & $\cdot$ & 50 \\
\hline
\end{tabular}

\section{Serum analysis}

Serum glucose, TG, TC, and HDLC levels were analyzed using enzymatic kits (Asan Pharmaceutical Co, Yongin, Korea).

\section{Western blot analysis}

For protein expression analysis, soleus muscle was homogenized on ice with a polytron homogenizer in $20 \mathrm{mmol} / 1$ Tris- $\mathrm{HCl}$ buffer ( $\mathrm{pH} 7.5$ ) containing $5 \mathrm{mmol} / 1$ EDTA, 2 $\mathrm{mmol} / 1 \mathrm{PMSF}$, and 1:200 protease inhibitor cocktail (Sigma, St Louis, MO, USA). The protein concentrations were determined using Bradford reagent (Bio-Rad, Hercules, CA, USA), with bovine serum albumin as the standard. An aliquot of tissue extract containing $20 \mu \mathrm{g}$ of protein (for PPAR$\delta$, PPAR- $\gamma$ and PGC-1a) was separated on a $10 \%$ SDS-PAGE gel. After electrophoresis, the proteins were transferred to a PVDF membrane (Millipore, Bedford, MA, USA) using a semi-dry blotting apparatus (Bio-Rad, Hercules, CA, USA). After treating with blocking buffer (PBS containing 10\% skim milk) for $90 \mathrm{~min}$, the membrane was incubated with primary polyclonal antibodies for $2 \mathrm{~h}$ (PPAR- $\delta$, PPAR- $\gamma$ and PGC-1a; Santa Cruz Biotechnology, CA, USA), followed by five $10 \mathrm{~min}$. washes with PBS (5\% Tween-20). The membrane was then incubated with HRP-conjugated anti-goat IgG or anti-rabbit IgG (Santa Cruz Biotechnology, CA, USA) for 1 $\mathrm{h}$, followed by five $10 \mathrm{~min}$. washes with PBS (5\% Tween-20). The target proteins were detected using an ECL kit (Amersham Pharmacia Biotech, Piscataway, NJ, USA). The films were photographed and the protein bands of interest were quantified using band analyzer software (Bio-Rad, Hercules, CA, USA).

\section{Statistical analysis}

All data were analyzed using SPSS software (version 16.0 for Windows). The data are expressed as the mean \pm SE, and values were analyzed with the independent samples $t$ test. Significance was defined as $p<0.05$.

\section{Results}

\section{Body weight gain and fat tissue weights}

In order to determine the effect of $O$. humifusa supplementation on the body weight gain and fat tissue weights, both body weight and fat tissue weights were measured by using a digital electronic balance. As shown in Table 3, body weight gain was slightly lower in the EG compared with the CG after 8 weeks of $O$. humifusa supplementation. However, the abdominal fat pad and epididymal fat pad were significantly smaller in the EG than in the CG $(p<0.05)$.

\section{Changes in serum parameters}

The enzymatic kits were used to estimate the effect of $O$. humifusa supplementation on serum parameters such as glucose, TG, HDLC, and TC. After the 8 weeks of the experiment, as shown in Table 4, the glucose, TG and TC concentrations of the EG were significantly lower than those of the CG $(p<0.01)$. Additionally, the HDLC concentration of the EG tended to be higher than that of the CG, but the difference was not significant.

Table 3. Comparison of body weight gain and fat tissue weights

\begin{tabular}{lcc}
\hline & CG & EG \\
\hline Body weight gain (g) & $193.0 \pm 11.86$ & $183.1 \pm 17.04$ \\
Abdominal fat pad (g) & $11.5 \pm 0.91$ & $8.5 \pm 0.70^{*}$ \\
Epididymal fat pad (g) & $11.3 \pm 0.91$ & $8.5 \pm 0.78^{*}$ \\
\hline
\end{tabular}

Data are expressed as the mean $\pm \mathrm{SE}$; CG: Control diet group; EG: Experimental diet group; ${ }^{*}, p<0.05$ compared with the CG.

Table 4. Changes in serum parameters

\begin{tabular}{lrc}
\hline & \multicolumn{1}{c}{ CG } & \multicolumn{1}{c}{ EG } \\
\hline Glucose $(\mathrm{mg} / \mathrm{dl})$ & $147.1 \pm 5.06$ & $119.9 \pm 2.57^{* *}$ \\
Triglyceride $(\mathrm{mg} / \mathrm{dl})$ & $36.0 \pm 2.69$ & $18.0 \pm 3.07^{* *}$ \\
HDLC $(\mathrm{mg} / \mathrm{dl})$ & $18.3 \pm 0.91$ & $21.0 \pm 1.08$ \\
TC $(\mathrm{mg} / \mathrm{dl})$ & $100.1 \pm 1.37$ & $78.4 \pm 5.05$ \\
\hline
\end{tabular}

Data are expressed as the mean $\pm \mathrm{SE}$; CG: Control diet group; EG: Experimental diet group; HDLC: high-density lipoprotein cholesterol; TC: total cholesterol; **, $p<0.01$ compared with the CG. 

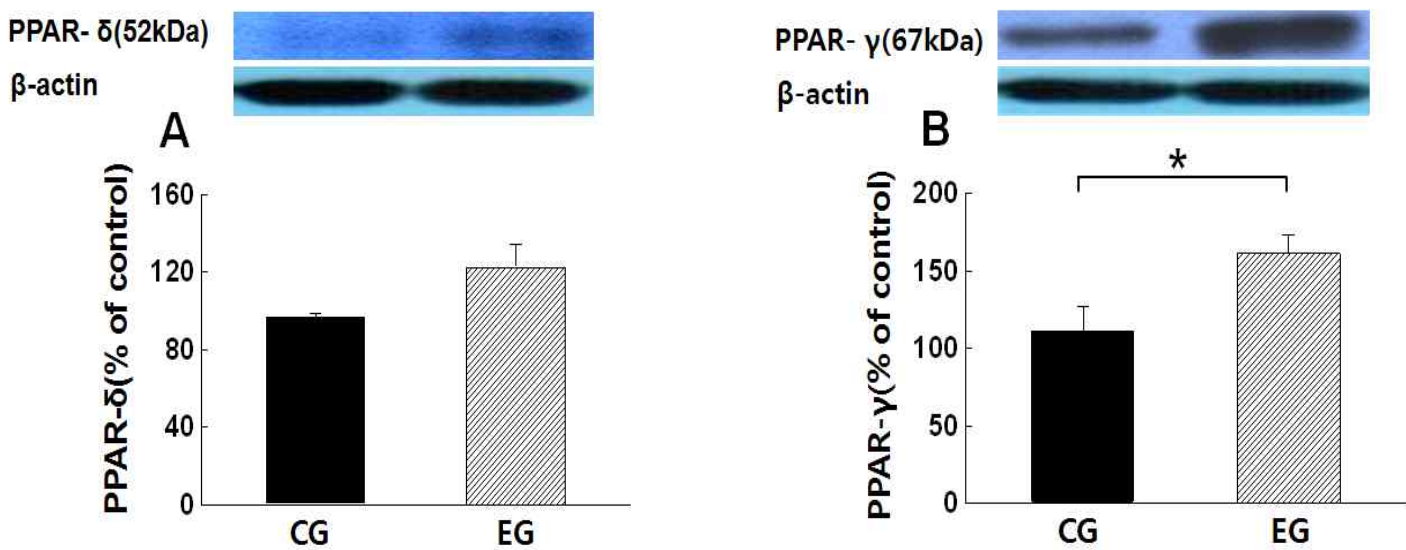

Fig. 1. Effect of $O$. humifusa supplementation on the expression levels of PPAR- $\delta$ and PPAR- $\gamma$ proteins in skeletal muscle. The data are expressed as the mean \pm SE. CG: Control diet group; EG: Experimental diet group; *, $p<0.05$; (A) PPAR- $\delta$; (B) PPAR- $\gamma$.
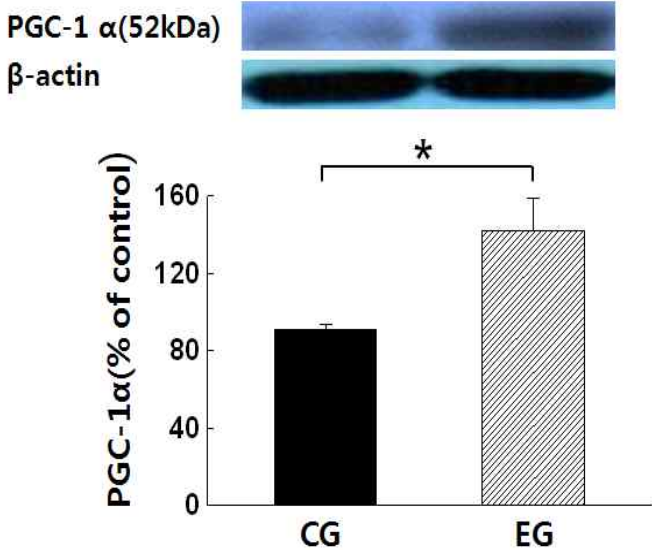

Fig. 2. Effect of $O$. humifusa supplementation on PGC-1a protein expressions in skeletal muscle. The data were expressed as the mean $\pm \mathrm{SE}$. CG: Control diet group; EG: Experimental diet group; *, $p<0.05$.

Skeletal muscle PPAR- $\delta$, PPAR $-\gamma$, and PGC-1a protein expressions

Western blot analysis was performed to analyze the PPAR- $\delta$, PPAR- $\gamma$, and PGC-1a protein expressions using homogenated soleus muscles. As shown in Fig. 1A, the expression of PPAR- $\delta$ protein in the EG tended to be higher than in the CG, but this difference was not significant. However, PPAR- $\gamma$ was significantly higher in the EG than in the CG $(p<0.05$, Fig. 1B). As shown in Fig. 2, PGC-1a protein expression in the EG was significantly higher than in the CG $(p<0.05)$.

\section{Discussion}

This study investigated the effect of $O$. humifusa supplementation on body weight and changes in fat weight as well as PPAR- $\delta, \gamma$ and PGC-1a protein expression on fatty acid metabolism in muscle tissue. In the present study, body weight was not significantly different between groups, whereas the PFT and EFT of the EG were significantly decreased compared with the CG. Increases in calcium intake, one of the major components of $O$. humifusa, have been shown to improve fatty acid oxidation by suppressing fatty acid synthase and thus reducing the intra-adipocyte calcium level through decrease parathyroid hormone secretion and reduced fat accumulation as well as increased lipolysis [36]. In a previous study, Teegarden et al. [31] reported that the rate of fat oxidation was significantly increased after 12 weeks of a 1,400 mg/day calcium-supplemented diet in obese women aged 18-31 compared with controls. We analyzed the nutritional composition of freeze-dried $O$. humifusa in the present study and found that, it contains $2,300 \mathrm{mg} / 100$ $\mathrm{g}$ of calcium. In addition, we calculated that the experimental diet group received approximately 1.3 times more calcium than the control group due to the $5 \%$ O. humifusa supplementation. In turn, fat oxidation of PFT and EFT in the EG was increased, which suppressed fat accumulation and increased lipolysis in the fat tissue of the EG, similar to what was observed in the previous study. Furthermore, we suggest that in the previous studies, increased expression of PPAR- $\delta$, PPAR- $\gamma$, and PGC- $1 a$ proteins activated fatty acid metabolism [16, 32], suggesting that increased PPAR- $\gamma$ and PGC-1a may have influenced fat weight reduction in the present study.

Serum analysis showed that serum glucose, TG, and TC of the EG were significantly decreased compared with the CG, and HDLC tended to increase in the EG compared with the Bwititi et al. [3] reported that orally humifusa extract 
supplementation $(20 \mathrm{mg} / 100 \mathrm{~g}$ body weight) lowers serum glucose levels through an insulin-independent mechanism in streptozotocin (STZ)-diabetic rats, and the glucose lowering effect was due to an increase in intracellular glucose uptake through the renal reabsorption of $\mathrm{Na}^{+}$after extract supplementation. In addition, it has been reported that insulin resistance was improved because TNF- $a$, which is a cytokine that is secreted from adipocytes and causes insulin resistance, is reduced by PPAR- $\gamma$ agonists [21]. Therefore, increased PPAR- $\gamma$ caused a reduction in glucose level in the present study. Meanwhile, it has been reported that increased lipoproteins such as TC, TG and LDLC cause hyperlipidemia during high-fat diet supplementation in a rat model $[13,35]$. However, fiber, which is also a component of $O$. humifusa, improved hyperlipidemia through by suppressing endogenous cholesterol synthesis by hindering intestinal fat absorption, increasing bile acid synthesis, and forming fatty acids with a lower number of carbons, which are degraded in the large intestine $[1,28]$. Similar to our present data, Hahm et al. [11] found that glucose, TG, TC and LDLC were significantly decreased in STZ-induced diabetic rats after oral supplementation with $250 \mathrm{mg} / \mathrm{kg} /$ day $O$. humifusa extract. It has been reported that supplementation with 2.5 $\mathrm{g} / 100 \mathrm{~g}$ diet prickly pear pectin, another cactus, has a positive effect on lowering serum lipid profiles in hyperlipidemia-induced guinea pigs [7], and serum LDLC, TG and TC levels are decreased by $O$. robusta administration in hyperlipidemic middle-aged men [33]. As a result, we might assume that the reduction in serum TG and TC levels in the EG is caused by an improvement in hepatic cholesterol metabolism due to increased intake of fiber and pectin with the $O$. humifusasupplemented diet.

Meanwhile, expression of PPAR $-\gamma$ and PGC- $1 a$ in the muscle in the EG was significantly increased compared with the CG, and PPAR- $\delta$ in the EG tended to increase in muscle tissue compared with the control group. Although PPAR- $\delta$ protein is expressed in various tissues, its expression is highest in muscle tissue [14], and it is involved in the catabolism of lipids as well as the regulation of energy uncoupling in skeletal cells [5]. Wang et al. reported that the activation of the PPAR- $\delta$ protein in adipocyte and skeletal muscle increased fat oxidation and utilization in an in vivo study using obese Zucker rats. Therefore, we suggest that $O$. humifusa supplementation partially affected fatty acid metabolism in muscles because an increasing tendency of PPAR- $\delta$ protein expression was observed after $O$. humifusa supplementation.
Meanwhile, although PPAR- $\gamma$ protein is highly expressed in adipose tissue, it is involved in fat oxidation-related gene expression in skeletal muscle tissue [19] and also plays an important role in lipid metabolism [9]. Similar to our present study, Kang et al. [17] reported that 8 weeks of $O$. humifusa supplementation increased PPAR- $\gamma$ protein expression in a rat model. We suggest that increased PPAR- $\gamma$ protein expression in the present study occurred through increased PGC-1a, which is a co-activator of PPAR- $\gamma$, due to intake of calcium-rich $O$. humifusa PGC-1a lead to PPAR expression as a co-activator and simulated mitochondrial biogenesis in muscle tissue as well as increased fatty acid oxidation through a transfer to slow twitch muscle fiber, which is favorable for fatty acid oxidation metabolism [25]. Calcium, in which $O$. humifusa is rich, plays an important role in the modulation of the intracellular signaling second messenger that leads to muscle contraction and gene expression. Increased calcium intake is highly involved in improving lipid metabolism, oxidative phosphorylation, mitochondrial biogenesis, and PGC-1a protein expression due to an increase in the activation of AMP-activated protein kinase (AMPK) and calcium/calmodulin-dependent protein kinase (CAMK) [15, 23, 34]. As a result, we suggest that the intake of calcium-rich $O$. humifusa increases the activation of intramuscular AMPK and CAMK by increasing the serum calcium level, resulting in the expression of PPAR- $\gamma$ and PGC-1 a, which are involved in lipid metabolism. Furthermore, as shown in a previous study, our results indicated that a reduction in fat weight, an improvement in serum lipid profiles, and a lowering of serum glucose level due to improvement of insulin sensitivity are caused by increased muscular PPAR- $\gamma$ and PGC-1a protein expression, which lead to the activation of fatty acid metabolism.

These results show that supplementation with $O$. humifusa for 8 weeks plays a positive role in lowering serum glucose and TG levels and suppressing weight gain by reducing fat weight through increasing the expression levels of PPAR- $\gamma$ and PGC-1a proteins in the muscle tissue of rats.

\section{Acknowledgement}

This research was supported by the Basic Science Research Program of the National Research Program through the National Research Foundation of Korea (NRF) funded by the Ministry of Education, Science and Technology (20110011951). 


\section{References}

1. Anderson, J. W. and Bridges, S. R. 1981. Plant fiber metabolites alter hepatic glucose and lipid metabolism. Diabetes 30, 133-139.

2. Arany, I. 2008. When less is more: apoptosis during acute kidney injury. Kidney Int 74, 261-262.

3. Bwititi, P., Musabayane, C. T. and Nhachi, C. F. 2000. Effects of Opuntia megacantha on blood glucose and kidney function in streptozotocin diabetic rats. J Ethnopharmacol 69, 247-252.

4. Dok-Go, H., Lee, K. H., Kim, H. J., Lee, E. H., Lee, J., Song, Y. S., Lee, Y. H., Jin, C., Lee, Y. S. and Cho, J. 2003. Neuro protective effects of antioxidative flavonoids, quercetin, (+)-dihydroquercetin and quercetin 3-methyl ether, isolated from Opuntia ficus-indica var. saboten. Brain Res 965, 130-136.

5. Dressel, U., Allen, T. L., Pippal, J. B., Rohde, P. R., Lau, P. and Muscat, G. E. 2003. The peroxisome proliferator-activated receptors $\beta / \delta$ agonist GW501516, regulates the expression of genes involved in lipid catabolism and energy uncoupling in skeletal muscle cells. Mol Endocrinol 17, 2477-2493.

6. Evans, R. M., Barish, G. D. and Wang, Y. X. 2004. PPARs and the complex journey to obesity. Nat Med 10, 355-361.

7. Fernandez, M. L., Lin, E. C. K., Trejo, A. and McNamara, D. J. 1994. Prickly pear (Opuntia sp.) pectin alters hepatic cholesterol metabolism without affecting cholesterol absorption in guinea pigs fed a hypercholesterolemic diet. J Nutr 124, 817-824.

8. Goldstein, G. and Nobel, P. S. 1994. Water relations and low-temperature acclimation forcactus species varying in freezing tolerance. Plant Physiol 104, 675-681.

9. Gorla-Bajszczak, A., Siegrist-Kaiser, C., Boss, O., Burger, A. G. and Meier, C. A. 2000. Expression of peroxisome proliferator-activated receptors in lean and obese Zucker rats. Eur J Endocrinol 142, 71-78.

10. Gurrieri, S., Miceli, L., Lanza, C. M., Tomaselli, F., Bonomo, R. P. and Rizzarelli, E. 2000. Chemical characterization of sicilian prickly pear (Opuntia ficus indica) and perspectives for the storage of its juice. J Agric Food Chem 48, 5424-5231.

11. Hahm, S. W., Park, J. and Son, Y. S. 2011. Opuntia humifusa stems lower blood glucose and cholesterol levels in streptozotocin-induced diabetic rats. Nutr Res 31, 479-487.

12. Handschin, C. and Spiegelman, B. M. 2008. The role of exercise and PGClalpha in inflammation and chronic disease. Nature 454, 463-469.

13. Harrison, D., Griendling, K. K., Landmesser, U., Hornig, B. and Drexler, H. 2003. Role of oxidative stress in atherosclerosis. Am J Cardiol 91, 7A-11A.

14. Hatakeyama, Y. and Scarpace, P. J. 2001. Transcriptional regulation of uncoupling protein-2 gene expression in L6 myotubes. Int J Obes Relat Metab Disord 25, 1619-1624.

15. He, Y. H., Li, S. T., Wang, Y. Y., Wang, G., He, Y., Liao, X. L., Sun, C. H. and Li, Y. 2012. Postweaning low-calcium diet promotes later-life obesity induced by a high-fat diet. J Nutr Biochem 23, 1238-1244.

16. Hu, S., Yao, J., Howe, A. A., Menke, B. M., Sivitz, W. I.,
Spector, A. A. and Norris, A. W. 2012. Peroxisome proliferator-activated receptor $\gamma$ decouples fatty acid uptake from lipid inhibition of insulin signaling in skeletal muscle. Mol Endocrinol 26, 977-988.

17. Kang, J. Y., Lee, J. H., Kwon, D. K. and Song, Y. J. 2013. Effect of Opuntia humifusa supplementation and acute exercise on insulin sensitivity and associations with PPAR- $\gamma$ and PGC-1a protein expression in skeletal muscle of rats. Int J Mol Sci 28, 7140-7154.

18. Kim, Y. J. and Park, T. S. 2008. Genes are differentially expressed in the epididymal fat of rats rendered obese by a high-fat diet. Nutr Res 28, 414-422.

19. Lapsys, N. M., Kriketos, A. D., Lim-Fraser, M., Poynten, A. M., Lowy, A., Furler, S. M., Chisholm, D. J. and Cooney, G. J. 2000. Expression of genes involved in lipid metabolism correlate with peroxisome proliferator-activated receptor gamma expression in human skeletal muscle. $J$ Cin Endocrinol Metab 85, 4293-4297.

20. Lin, J., Puigserver, P., Donovan, J., Tarr, P. and Spiegelman, B. M. 2002. Peroxisome proliferator-activated receptor gamma coactivator 1beta (PGC-1beta), a novel PGC-1-related transcription coactivator associated with host cell factor. $J$ Biol Chem 277, 1645-1648.

21. Miles, P. D., Romeo, O. M., Higo, K., Cohen, A., Rafaat, K. and Olefsky, J. M. 1997. TNF-alpha-induced insulin resistance in vivo and its prevention by troglitazone. Diabetes 46, 1678-1683.

22. Norris, A. W., Chen, L., Fisher, S. J., Szanto, I., Ristow, M., Jozsi, A. C., Hirshman, M. F., Rosen, E. D., Goodyear, L. J., Gonzalez, F. J., Spiegelman, B. M. and Kahn, C. R. 2003. Muscle-specific PPAR $\gamma$-deficient mice develop increased adiposity and insulin resistance but respond to thiazolidinediones. J Cin Invest 112, 608-618.

23. Ojuka, E. O. 2004. Role of calcium and AMP kinase in the regulation of mitochondrial biogenesis and GLUT4 levels in muscle. Proc Nutr Soc 63, 275-278.

24. Park, E. H., Kahng, J. H. and Paek, E. A. 1998. Studies on the pharmacological actions of cactus: identification of its anti-inflammatory effect. Arch Pharm Res 21, 30-34.

25. Petersen, K. F., Befroy, D., Dufour, S., Dziura, J., Ariyan, C., Rothman, D. L., DiPietro, L., Cline, G. W. and Shulman, G. I. 2003. Mitochondrial dysfunction in the elderly: possible role in insulin resistance. Science 300, 1140-1142.

26. Russell, A. P., Hesselink, M. K., Lo, S. K. and Schrauwen, P. 2005. Regulation of metabolic transcriptional co-activators and transcription factors with acute exercise. FASEB J 19, 986-988.

27. Sears, I. B., MacGinnitie, M. A., Kovacs, L. G. and Graves, R. A. 1996. Differentiation-dependent expression of the brown adipocyte uncoupling protein gene: regulation by peroxisome proliferator-activated receptor gamma. $\mathrm{Mol} \mathrm{Cell}$ Biol 16, 3410-3419.

28. Story, J. A. 1981. The role of dietary fiber in lipid metabolism. Adv Lipid Res 18, 229-246.

29. St-Pierre, J., Lin, J., Krauss, S., Tarr, P. T., Yang, R., Newgard, C. B. and Spiegelman, B. M. 2003. Bioenergetic 
analysis of peroxisome proliferator-activated receptor gamma coactivators 1alpha and 1beta (PGC-1alpha and PGC-1beta) in muscle cells. J Biol Chem 278, 26597-26603.

30. Sun, X. and Zemel, M. B. 2004. Calcium and dairy products inhibit weight and fat regain during ad libitum consumption following energy restriction in Ap2-agouti transgenic mice. J Nutr 134, 3054-3060.

31. Teegarden, D., White, K. M., Lyle, R. M., Zemel, M. B., Van Loan, M. D., Matkovic, V., Craig, B. A. and Schoeller, D. A. 2008. Calcium and dairy product modulation of lipid utilization and energy expenditure. Obesity (Silver Spring) 16, 1566-1572.

32. Wang, Y. X., Lee, C. H., Tiep, S., Yu, R. T., Ham, J., Kang, H. and Evans, R. M. 2003. Peroxisome-proliferator-activated receptor delta activates fat metabolism to prevent obesity. Cell 113, 159-170.
33. Wolfram, R. M., Kritz, H., Efthimiou, Y., Stomatopoulos, J. and Sinzinger, H. 2002. Effect of prickly pear (Opuntia robusta) on glucose- and lipid-metabolism in non-diabetics with hyperlipidemia - a pilot study. Wien Klin Wochenschr 114, 840-846.

34. Wu, H., Kanatous, S. B., Thurmond, F. A., Gallardo, T., Isotani, E., Bassel-Duby, R. and Williams, R. S. 2002. Regulation of mitochondrial biogenesis in skeletal muscle by CaMK. Science 12, 349-352.

35. Yang, R., Le, G., Li, A., Zheng, J. and Shi, Y. 2006. Effect of antioxidant capacity on blood lipid metabolism and lipoprotein lipase activity of rats fed a high-fat diet. Nutrition 22, 1185-1191.

36. Zemel, M. B., Shi, H., Greer, B., Dirienzo, D. and Zemel, P. C. 2000. Regulation of adiposity by dietary calcium. FASEB J 14, 1132-1138.

\section{초록 : 손바닥선인장 보충이 고지방식이 흰쥐 골격근의 PPAR- $\gamma$ 와 PGC-1a 단백질 발현 증가에 미치는 영향}

권대근 · 강준용 · 김재승 · 송영주*

(선문대학교 스포츠영양학실)

본 연구는 안정 시 고지방식이 흰쥐의 골격근에서 PPAR-8, PPAR- $\gamma$ 그리고 PGC-1a 단백질 발현에 손바닥선인 장 보충이 미치는 효과에 대하여 연구하였다. SD계 수컷 흰쥐 16 마리를 무작위로 대조군(CG, $\mathrm{n}=8$ )과 실험군(EG, $\mathrm{n}=8$ )으로 분류하였다. 8 주 동안 대조군은 고지방식이를 부하하였으며, 실험군은 $5 \%$ 손바닥선인장을 보충식이하 였다. 본 실험결과, 복부지방과 고환부 지방 중량은 EG군이 CG군에 비해 유의하게 낮게 나타났다( $p<0.01)$. 또한 혈당, 중성지방, 총콜레스테롤의 농도도 EG군이 CG군에 비해 유의하게 낮게 나타났다( $p<0.01)$. 한편, 골격근에서 PPAR- $\gamma$ 와 PGC- $1 \mathrm{a}$ 단백질 발현은 EG군이 CG군에 비해 유의하게 높게 나타났다( $p \times 0.05)$. 이상의 결과로부터 손 바닥선인장 보충이 고지방식이 흰쥐의 혈당과 중성지방 농도의 감소와 골격근에서 PPAR- $\gamma$ 와 PGC- $1 a$ 단백질 발 현을 증가시킴으로서 체지방을 감소시켜 체중증가 억제에 긍정적인 영향을 미치는 것으로 나타났다. 